\title{
COVID-19 Course of Infection and Disease
}

\author{
Suneel Piryani ${ }^{1}$, Rano Mal Piryani2 ${ }^{\star}$ Ganesh Dangal ${ }^{3}$
}

Author Info:

'Public Health Consultant, Karachi Pakistan

2Professor of Internal Medicine, Head Department of Internal Medicine and Chief Coordinator- Health Professions Training Committee, Coordinator COVID-19 Task Committee, Universal College of Medical Sciences, Bhairahawa, Nepal

${ }^{3}$ Professor and Academic Chief of Department of Obstetrics and Gynecology, Kathmandu Model Hospital, Nepal *Corresponding Author:

Dr. Rano Mal Piryani; E mail: rano.piryani@gmail.com

\section{Dear Editor,}

COVID-19 course of infection and disease. World Health organization declared COVID-19, a global pandemic on March 11, 2020. This has had far reaching impact on lives of the people, health care systems, community and economy of all countries worldwide. COVID-19 is a multisystem disorder primarily affecting the lungs transmitted mainly through droplet infection. ${ }^{1}$ The estimated range of incubation period for COVID-19 is 2-14 days from the time of exposure, with a median incubation period of 4 to 5 day's. $^{2-3}$

Based on the severity of illness, adults with COVID-19 are grouped into five categories, even though the criteria in each category may overlap; asymptomatic/pre-symptomatic infection, mild illness, moderate illness, severe illness and critical illness. ${ }^{3}$ As per Center for Disease Control and Prevention (CDC) USA, around one third of the patients infected with COVID-19 may remain asymptomatic but can transmit the disease while among the symptomatic, around $80 \%$ develop mild to moderate disease, while $15 \%$ develop severe lower respiratory tract infection, 3-5\% develop critical illness and $0.5-1 \%$ of patients die. ${ }^{4}$

Frequently cited estimate is that most people recover from 'mild' infections within two weeks and more serious disease within three weeks. ${ }^{3}$ Patients who had recovered from COVID-19, majority reported the persistence of one or more symptoms, particularly fatigue and dyspnea. ${ }^{4}$

Various names have been given to these post recovery presentations such as "Long Covid" or "Long Haul Covid" "Ongoing Covid19". It is yet to be proven whether the symptoms of all of these people are due to the same phenomenon or any other explanation for these presentations is there.

\begin{tabular}{|c|c|}
\hline QR Code & Article Info \\
\hline$\triangle$ View PDF & Published Online: 25 January 2021 \\
\hline \multirow{3}{*}{ aripar } & How to cite this article in Vancouver Style? \\
\hline & $\begin{array}{l}\text { Piryani RM, Piryani S, Dangal G. COVID-19 Course of Infection and Disease. Europasian J Med Sci. 2021; 3(1): } \\
\text { https://doi.org/10.46405/ejms.v3i1.308 }\end{array}$ \\
\hline & Disclaimer \\
\hline & Conflict of Interest: None Declared; \\
\hline \multicolumn{2}{|c|}{$\begin{array}{l}\text { Copyright: ( } 2021 \text { by author(s). This work is licensed under the terms and condition of Creative Commons Attribution International License } 4.0 \text { (@) } \\
\text { (http://creativecommons.org/licenses/by/4.0/) which permits unrestricted use, distribution, and reproduction in any medium, provided the original work is } \\
\text { properly cited. This is an open access publication, and can be downloaded freely from the website of the Journal: www.europasianjournals.org. The Journal } \\
\text { as well as publisher remain neutral with regards to any jurisdictional claims in any published articles, its contents and the institutional affiliations of the } \\
\text { authors. The Europasian Journal of Medical Sciences (EJMS) (www.europasianjournals.org) is an official Journal of Nirvana Psychosocial Care Center \& } \\
\text { Ressearch Institute (www.nirvanapscc.com). }\end{array}$} \\
\hline
\end{tabular}




\section{COVID-19 course of infection and disease}

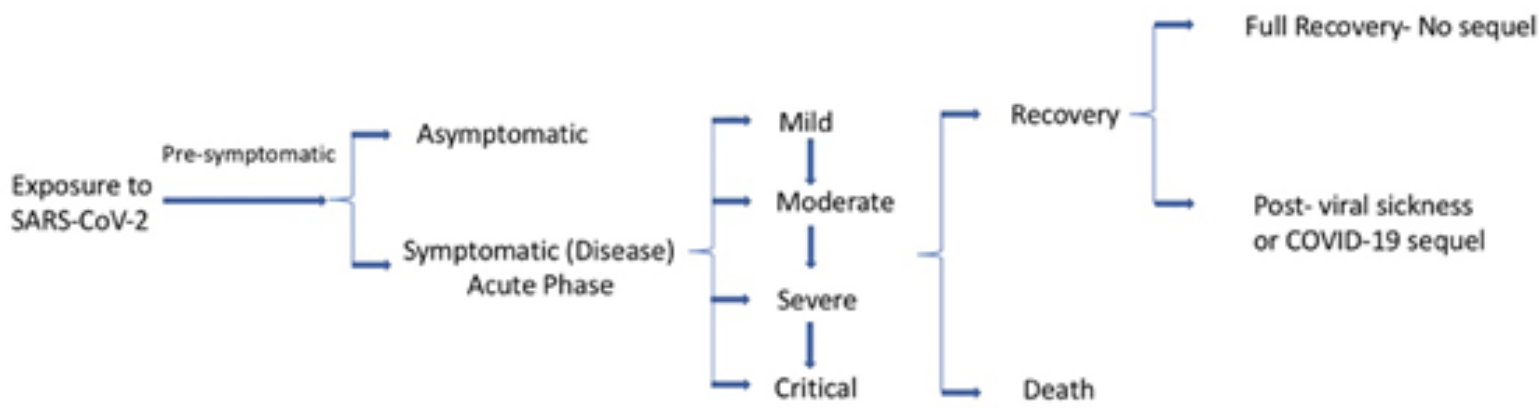

Infectious period

Virus grows on culture

12-14 days
Post Infectious period

Weeks-Months
5 days

(2-21 days

Piryani RM, Piryani S, Dangal G

Figure 1: COVID-19 course of infection and disease

Healthcare community are still in process of understanding the pathogenesis of disease in depth, hence there is need to be cautious in drawing conclusions hastily. ${ }^{1,5}$ We have framed the COVID-19 course of infection and disease based on the mentioned facts. In this we have mentioned the sickness of this group of patients as post viral sickness or COVID-19 sequel. (Figure 1)

\section{REFERENCES}

1. Living with COVID-19. Elaine Maxwell NIHR CED 30 September 2020. [Link]

2. Living with COVID-19. Elaine Maxwell NIHR CED 30 September 2020. Accessed on October 18, 2020. [Link].

3. COVID-19- Coronavirus Pandemic. Accessed on October 17, 2020. [Link]

4. COVID-19 Treatment Guidelines Panel. Coronavirus Disease 2019 (COVID-19) Treatment Guidelines. National Institutes of Health. Accessed on October 17, 2020. [Link]

5. Center for Disease Control and Prevention. Coronavirus Disease 2019- Clinical Care Guidance updated June 30, 2020. Accessed on July 11, 2020. [Link]
6. Carfì A, Bernabei R, Landi F, for the Gemelli Against COVID-19 Post-Acute Care Study Group. Persistent Symptoms in Patients After Acute COVID-19. JAMA. 2020;324(6):603-605. https://doi. org/10.1001/jama.2020.12603 